\title{
HOW UNIVERSITY STUDENTS AS NON NATIVE ENGLISH SPEAKERS PERFORM FACE THREATENING ACTS ${ }^{1}$
}

\author{
Ronald Maraden Parlindungan Silalahi* \\ English Language and Culture Department, Bunda Mulia University \\ Received on 1 October 2018 / Approved on 15 October 2018
}

\begin{abstract}
Politeness is necessary in any social interaction to avoid conflict which might arise because of the utterances. Politeness elaborates that we all have 'face' of wants and needs, when the wants and needs are not fulfilled properly, then a Face-Threatening Act (FTA) is executed (Lakoff, 1973). There are all sorts of FaceThreatening Acts, and sometimes the face threats are directed to the hearer, while in some other times they are aimed to the first speaker (Brown \& Levinson, 1987). The students of Non-Native English Speaker (NNES) become the source data of this study. The way they perform the FTA based on circumstances, which are Power, Social Distance, and Imposition (Brown \& Levinson, 1987). While performing FTA, the students have different ways of applying it in their daily lives. The greatest possibility is that the students might use politeness strategy to minimize FTA, by using negative politeness and positive politeness, which theory comes from Brown and Levinson (1987). Qualitative approach is used in this study, while the method is test analysis. The data is using Discourse Completion Test (DCT) of Politeness regarding various situations to perform FTA and it will be delivered to all University students. The result can be seen that most of the respondent's answers are identical to the expected answers from the data collectors. This proves that most of NNES are able to perform FTA appropriately, moreover when it is associated with politeness. The purpose of this study is to describe students' comprehension, as well as to provide learning to who are not English native speakers, about FTA and ways that can be applied to perform FTA. It is expected that this study will help students to figure out about the function of FTA and understand more on how to perform FTA.
\end{abstract}

Keywords: politeness, face threatening acts, non native English speakers, university students

\section{ABSTRAK}

Kesopanan diperlukan dalam setiap interaksi sosial untuk menghindari konflik yang mungkin timbul karena pengucapan. Kesopanan menjelaskan bahwa kita semua memiliki 'muka' akan keinginan dan kebutuhan, ketika keinginan dan kebutuhan tidak terpenuhi dengan benar, maka Tindakan Mengancam Wajah (Face Threatening Acts atau FTA) akan dilakukan (Lakoff, 1973). Ada berbagai macam Tindakan yang Mengancam Wajah, dan terkadang ancaman tersebut ditujukan kepada pendengar, sementara di lain waktu mereka ditujukan kepada pembicara pertama (Brown \& Levinson, 1987). Para siswa yang bukan penutur asli bahasa Inggris (Non Native English Speakers atau NNES) menjadi sumber data dari penelitian ini. Cara mereka melakukan FTA berdasarkan keadaan, yaitu Kuasa (Power), Jarak Sosial (Social Distance), dan Pembebanan (Imposition) (Brown \& Levinson, 1987). Saat melakukan FTA, para siswa memiliki berbagai cara untuk menerapkannya dalam kehidupan sehari-hari mereka. Kemungkinan terbesar adalah bahwa siswa mungkin menggunakan strategi kesantunan untuk meminimalkan FTA, dengan menggunakan kesopanan negatif dan kesopanan positif, yang teorinya berasal dari Brown dan Levinson (1987). Penelitian ini dilakukan dengan pendekatan kualitatif, sedangkan metodenya adalah uji analisis. Data tersebut menggunakan Discourse Completion Test (DCT) dari Kesopanan yang berkaitan dengan berbagai situasi untuk melakukan FTA dan akan dikirimkan ke sетиа mahasiswa di Universitas manapun. Hasilnya dapat dilihat bahwa sebagian besar

\footnotetext{
${ }^{1}$ This article is a part of 2015 class project for Introduction to Semantic and Pragmatic subject in English Language and Culture in Bunda Mulia University. The article has electronically been proof read with $100 \%$ uniqueness without any act of plagiarism.
}

*Author(s) Correspondence:

E-mail: rsilalahi@bundamulia.ac.id 
jawaban responden mirip dengan jawaban yang diharapkan dari pengumpul data. Ini membuktikan bahwa sebagian besar NNES mampu melakukan FTA dengan tepat, apalagi ketika dikaitkan dengan kesopanan. Tujuan dari penelitian ini adalah untuk menggambarkan pemahaman siswa, serta untuk memberikan pembelajaran kepada yang bukan penutur asli bahasa Inggris, tentang FTA dan cara-cara yang dapat diterapkan untuk melakukan FTA. Diharapkan bahwa penelitian ini akan membantu siswa untuk mengetahui tentang fungsi FTA dan memahami lebih lanjut tentang bagaimana melakukan FTA.

Kata Kunci: kesopanan, tindakan mengancam muka, bukan penutur asli bahasa Inggris, siswa universitas

\section{INTRODUCTION}

\subsection{Background of the Study}

We acknowledge politeness as one of the necessary elements needed in society. When we are talking with strangers, acquaintances, friends, family, and people in higher position, we have sets of linguistic repertoire, a various language for different situation and interlocutors (Holmes, 2001). Not only that we understand how to display politeness, but also understand when other people is being polite or not. For instance, people behave politely when they show respect towards their superiors; being helpful, courteous, and less likely to talk about private matter. However, for NNES, the circumstance can be different when they deliver an utterance because of distinct culture and common behavior.

Moreover, according to Brown and Levinson (1987), there are two kinds of politeness strategies which are usually used in order to perform an act, the first one is negative politeness strategies, which tend to show respect in order to avoid giving offensive acts/utterances, such as questioning and presenting disagreements as opinions. The other one is positive politeness strategies which tend to highlight friendliness while talking in order to avoid giving offensive acts/utterances such as giving compliments, and using jokes.

Thus, not only is it the speaker's responsibility but also how the hearer responds on the role of delivering utterances in an apparent and efficient manner to indicate certain degree of politeness (Grice, 1975). For example, when someone is requesting another to open a window by saying "It's warm in here" is to perform the request politely because one did not use the most efficient way for performing this act (i.e., open the window). From the example, we can conclude that politeness allows people to perform many interpersonal sensitive actions in a nonthreatening or less threatening manner. This concept is also intended for non-native speakers to have a view of politeness in the use of everyday language, especially for the NNES in University in interacting with various people with different Power, Social Distance, and Imposition.

\subsection{Scope and Limitation}

This research analyzed the respond from the participants regarding 8 different situations with various circumstances related to Power, Social Distance, and Imposition, whether the responds are already appropriate or not depending on the situation. This study only request University students who are not NNES to answer a Discourse Completion Test via online in order to help finish the research in a shorter extent.

\subsection{Research Questions}

The research questions in this study are in the following:

1. Are NNES, especially University students, able to perform FTA appropriately depending on the situation?

2. In which situation do NNES, especially University students, able to perform FTA appropriately with low probability of failure?

\subsection{Objective}

The main objective of this study accomplished by the researchers is to analyze

\footnotetext{
*Author(s) Correspondence:

E-mail: rsilalahi@bundamulia.ac.id
} 
whether the Non-Native English Speakers understand and know how to perform Face Threatening Acts regarding the particular circumstances.

\subsection{Significance}

The significance of this research is to show University students' ability as NNES in performing Face Threatening Acts and to point out the appropriate responds for appropriate situations which can be done by everyone, teachers and students, regarding the Power, Social Distance, and Imposition.

\section{THEORETICAL REVIEW}

The following theories stated as the basis of this research:

\subsection{Non-Native English Speaker}

Moussu (2006), in her thesis, explained that Non-Native English Speaker is a person whose first language is not English and learn English intentionally from formal school. They acquire the ability to speak and develop their English language through academic process, yet still acknowledged as a Non-Native English Speaker because only people who learn English unconsciously as their first language are considered as Native English Speakers.

Hence, the researchers intend to ask help from College students in all major and all University as the participants, for they are Non Native English Speakers which understand English as their second language.

\subsection{Development of Speech Act}

It first began with Austin (1962) that explained Speech Act as an act to deliver utterance which has different meaning for the speaker and the hearer rather than the meaning of the language. Later, Searle developed Austin's Speech Act, which focus more on the illocutionary acts (Searle, 1965).

Then followed by Grice's creation of Maxims as Cooperative Principles (Grice, 1975), which purpose was to separate between direct speech act and implicature. Grice's 4
Maxims (Quality, Quantity, Relevance, and Manner) analyzed the relation between the utterance and the intended meaning. If the utterance violated one of the maxims, it means that the speaker is trying to imply something.

\subsection{Politeness Theory}

However, this development was still considered as incomplete because the intention of speech act was not only to utter something based on context, but also to maintain social relation. And so, the Politeness Theory was proposed by Lakoff (1973) and Brown and Levinson (1999). Lakoff came up with Politeness Principles; which were (1) Don't impose; (2) Give options; (3) Make the hearer comfortable and be friendly.

Brown and Levinson offered assumptions that all member of society had (1) 'Face' and (2) Certain Rational Capacities. They continued with the possibilities of Face Threatening Act.

\section{4. 'Face' \& Face Threatening Act}

Brown and Levinson (1999) identified two related aspects in 'face'. First is negative face which is related to claim of territories, self conserve, the right of non distraction and freedom. Second is positive face which is related to the positive image of personality that need appreciation and acceptance.

Brown and Levinson (1999) also stated that face is something that is emotionally invested that may receive influence and thus, resulting in loss, maintenance, or enhancement that have to be frequently applied in interaction. Usually, people work together to maintain the face because one face depends on other's behavior and may be threaten, either to the negative face or the positive face.

Intrinsic FTA happens when the speaker spontaneously and deliberately utters something that may have threatened the hearer's face with particular intention. There is a strategy for this, depends on the needs to: Communicate the Content, Efficiency / Urgency, and Minimizing the FTA (Brown \& Levinson, 1999).

*Author(s) Correspondence:

E-mail: rsilalahi@bundamulia.ac.id 
There are 3 circumstances of sociological variables that affect the chance of FTA and the result of the various level of FTA to the hearer's face (Brown \& Levinson, 1999);

1. The Social Distance

The symbol $(+)$ show a close social distance, for example in family relations, close friends, married couple, childhood friends, etc.

The symbol (-) show a far social distance, for example strangers, acquaintances, classmates, etc.

2. The Relative Power

The symbol (+) show an existence of authority in the relation between the speaker and the hearer, for example employer and employee, student and principal, etc.

The symbol (-) show a non-existence of authority in the relation between the speaker and the hearer, for example, friends, colleagues, group members, etc.

3. The Absolute Ranking of Imposition The symbol $(+)$ show an existence of urgency or importance of the situation, for example in accidents, important meeting, big projects due to deadline, etc.

The symbol (-) show a non-existence of urgency or importance of the situation, for example requesting a cup of tea, lunch invitation, small projects, etc.

\subsection{Discourse Completion Test Politeness}

Based on Discourse Completion Test written by Rose (1994), there are 8 situations between a speaker and a hearer with different circumstances of Power, Social Distance, and Imposition. The respondents are requested to give their own responds which they consider as appropriate. The DCT provided here has been modified by the researchers from Rose's (1994).

\subsection{Surveymonkey}

www.surveymonkey.com is a website to provide assistance to researchers who need to give questionnaires for surveys and data collection, designed to help the researcher in understanding the data from participants or target markets.

\section{METHODOLOGY}

\subsection{Research Design}

This research is a qualitative research for the researchers are going to be the one who analyze the responds given by the respondents through the DCT.

\subsection{Participants}

University students from all college are accepted as the respondents of the study and the researchers managed to gather a total of 28 to 29 respondents.

\subsection{Data Collection}

The researchers modified the 8 questions of the DCT along with the appropriate answers with identifed circumstances of Power, Social Distance, and Imposition between a speaker and a hearer. The decisions of the responds are based on the answers provided by the researcher.

\section{Appropriate}

When the symbol of circumstances of the analyzed responses are the same with the provided answers.

\section{Inappropriate}

When the symbol of circumstances of the analyzed responses are different with the provided answers.

\section{Unrelated}

When the respondents give answers which have no relation with the questions or give incomplete responds.

However, before the researchers decide on the symbol of the circumstances of the respondents' answer, the researchers analyze the meaning of the responses and not the similarity of answer with the provided answer from the researchers. Thus, if the responses are in a different form than the provided answers but have similar meaning, the researchers may deem the responses as appropriate.

\footnotetext{
*Author(s) Correspondence:

E-mail: rsilalahi@bundamulia.ac.id
} 
For example:

Question: You were asked by your best friend to buy a box of cereal but you are busy.

What would you say?

Appropriate answer provided by the researchers:

$\Rightarrow$ Sorry, can't do it. I'm busy right now.

Respondent's response:

$\Rightarrow$ I'm sorry, I'm busy so I can't do it.

This response is considered as Appropriate because the meaning is still the same with the provided answer. The point is that the hearer should apologize and explain why they cannot do the request.

Another respondent's response:

$\Rightarrow$ No, I can't.

This response is considered as Inappropriate because even though the respondent respond to the situation in a refusal, they haven't reach the appropriate and intended meaning. They don't apologize and stated why they can't do the request.

The other respondent's respond:

$\Rightarrow$ Even if I'm busy, I will spare my time to buy what my best friend has requested.

This respond is considered as Unrelated because the answer given by the respondent has no any relation with the situation where the respondent should refuse and apologize by giving reason.

\subsection{Data Collection Procedures}

The data collection procedure in this study is as follows:

1. The researchers input the modified 8 questions of DCT into the website of Surveymonkey.

2. The researchers share the link to all university students who are not NNES.

3. The respondents answer all the questions via online.
4. The researchers analyze the answers given by the respondents and decide whether the answers are appropriate, inappropriate, or unrelated, based on the designated circumstances based on theory proposed by Brown and Levinson (1999).

\section{FINDINGS}

The analysis of findings is from Discourse Completion Test which has been modified from Rose's (1994) DCT, it consists of 8 questions for 8 different situation between a speaker and a hearer with relations with the circumstances of Power, Social Distance, and Imposition, and the respondents are asked to respond to the situations based on their own way. Then the researchers analyzed whether their responds are already appropriate or not based on Brown and Levinson's (1999) theory.

The order of circumstances and symbols are as follow:

$>$ Item 1: Power $=(+)$; Social distance $=$ $(+)$; Imposition $=(+)$

$>$ Item 2: Power $=(+)$; Social distance $=$ $(+)$; Imposition $=(-)$

$>$ Item $3:$ Power $=(+)$; Social distance $=$ $(-) ;$ Imposition $=(+)$

$>$ Item 4: Power $=(-)$; Social distance $=$ $(-) ;$ Imposition $=(-)$

$>$ Item 5 : Power $=(-)$; Social distance $=$ $(-)$; Imposition $=(+)$

$>$ Item 6 : Power $=(-)$; Social distance $=$ $(+)$; Imposition $=(-)$

$>$ Item 7 : Power $=(-)$; Social distance $=$ $(+)$; Imposition $=(+)$

$>$ Item $8:$ Power $=(+)$; Social distance $=$ $(-) ;$ Imposition $=(-)$

The symbol (+) marks the existence of the circumstances, such as the existence of authority, the close social relation, and the urgency of imposition, while the symbol (-) marks otherwise, such as the vacancy of authority, the distant social relation, and no urgency of imposition.

*Author(s) Correspondence:

E-mail: rsilalahi@bundamulia.ac.id 
Finding results from Item 1 to Item 8:

\section{Item 1}

A businessperson asked you, his/her housekeeper who had been working for 10 years, to bring an important document that he/she forgot at home, but you were doing an important errand that you could not left.

$$
\text { Power }=(+) \text {; Social distance }=(+) \text {; Imposition }=(+)
$$

What would you say?

$\rightarrow$ I'm really sorry, Sir, but I have something that I can't left. Can I please do it after I have finished my errand?

The above answer provided by the researchers is considered as Appropriate because:

1. The existence of the power, thus as the hearer, we respond with additional title to the speaker which is 'Sir'. The formal way of speaking also included here.

2. The close relation between the speaker and hearer because of the 10 years work period, thus the hearer may refuse the order from the higher position and give a reason why.

3. The importance of the command which the hearer understands, so the hearer will offer another way or do the request afterwards.

Some of the respondents' responses which the researchers considered as Appropriate are:

Table 1. Respondent's Responses

\begin{tabular}{|c|l|}
\hline $\begin{array}{c}\text { Respondent's } \\
\text { Number }\end{array}$ & \multicolumn{1}{c|}{ Responses } \\
\hline 2 & $\begin{array}{l}\text { I'm really sorry I can't do that but I'll find a way to give it to you as soon } \\
\text { as possible }\end{array}$ \\
\hline 3 & $\begin{array}{l}\text { Sorry, I could not do it now because I have an important duty that I could } \\
\text { not left, May I bring later after I have done the duty ? }\end{array}$ \\
\hline 4 & Sorry, Sir can I do it later, I need to do some errands. \\
\hline 5 & $\begin{array}{l}\text { I'm sorry sir, I cannot bring it by myself. Instead, I'll ask another person } \\
\text { to bring ir safely. }\end{array}$ \\
\hline 6 & $\begin{array}{l}\text { I would say like"sorry, sir/maam...im working and i couldnt left it. Would } \\
\text { you able to waiting? After im done, im going to do what you demand" } \\
\text { that's it. }\end{array}$ \\
\hline 8 & $\begin{array}{l}\text { I'm so sorry I can't bring the document to you because I am doing } \\
\text { something that also important for me. }\end{array}$ \\
\hline 11 & $\begin{array}{l}\text { Sorry sir/ma'am, I could not deliver the document because I'm doing an } \\
\text { important thing right now, do you mind if you wait until I finished my } \\
\text { work? I am so sorry to say this, but if you are in rush, maybe I will send } \\
\text { the document by online services (GoSend, JNE, etc). Thank you } \\
\text { sir/ma'am. }\end{array}$ \\
\hline & $\begin{array}{l}\text { If you would not mind, could you wait a little bit longer? I have things i } \\
\text { could not left behind, but i will get there as soon as possible. }\end{array}$ \\
\hline
\end{tabular}

*Author(s) Correspondence:

E-mail: rsilalahi@bundamulia.ac.id 


\begin{tabular}{|c|l|}
\hline 12 & $\begin{array}{l}\text { Sorry Miss/Mr, can I give it to you later on after I finished my important } \\
\text { errand? I will make sure to give it to you soon. }\end{array}$ \\
\hline 14 & $\begin{array}{l}\text { I'm sorry I can't, but I try to finish my business as soon as possible and } \\
\text { bring the document. }\end{array}$ \\
\hline
\end{tabular}

The total responses from 29 respondents are as follow:

- Appropriate Answers: 16

- Inappropriate Answers: 9

- Unrelated Answers: 4

Table 2. Total Respondents' Responses

\begin{tabular}{|c|c|c|c|c|}
\hline $\begin{array}{c}\text { Respondent } \\
\text { Number }\end{array}$ & Power & $\begin{array}{c}\text { Social } \\
\text { Distance }\end{array}$ & Imposition & Conclusion \\
\hline 1 & + & + & + & Unrelated \\
\hline 2 & + & + & + & Appropriate \\
\hline 3 & + & + & + & Appropriate \\
\hline 4 & + & + & + & Appropriate \\
\hline 5 & + & + & + & Appropriate \\
\hline 6 & + & + & + & Appropriate \\
\hline 7 & + & + & + & Appropriate \\
\hline 8 & + & + & + & Appropriate \\
\hline 9 & - & - & + & Inappropriate \\
\hline 10 & - & - & - & Inappropriate \\
\hline 11 & + & + & + & Appropriate \\
\hline 12 & + & + & + & Appropriate \\
\hline 13 & - & - & + & Inappropriate \\
\hline 14 & + & + & + & Appropriate \\
\hline 15 & + & + & + & Appropriate \\
\hline 16 & + & + & + & Appropriate \\
\hline 17 & - & - & - & Unrelated \\
\hline 18 & - & + & - & Unrelated \\
\hline 19 & + & + & + & Appropriate \\
\hline 20 & + & + & + & Appropriate \\
\hline 21 & - & - & + & Inappropriate \\
\hline 22 & - & + & + & Unrelated \\
\hline 23 & - & - & + & Inappropriate \\
\hline 24 & + & + & + & Appropriate \\
\hline 25 & + & + & + & Appropriate \\
\hline 26 & - & - & + & Inappropriate \\
\hline 27 & - & + & + & Inappropriate \\
\hline 28 & + & - & + & Inappropriate \\
\hline 29 & - & + & + & Inappropriate \\
\hline & & & & \\
\hline & + & + & + & + \\
\hline
\end{tabular}

*Author(s) Correspondence:

E-mail: rsilalahi@bundamulia.ac.id 
In this situation, most respondents are able to answer appropriately and politely according to their position. The inappropriate answers are because no title stated in the responses. The unrelated answers are because the respondents give incomplete answer or get confused with the question.

\section{Item 2}

You, a company director, ask your employee, who used to be your classmate at university, to make you a cup of tea.

$$
\text { Power }=(+) \text {; Social distance }=(+) ; \text { Imposition }=(-)
$$

What would you say?

Make me some tea. Cause I'm thirsty.

The above answer provided by the researchers is considered as Appropriate because:

1. The existence of the power, thus as the speaker, we give command with a less polite manner. The informal way of speaking also included here.

2. The close relation between the speaker and hearer as classmate, thus the speaker talks in a straightforward manner without saying 'please' or as the need to ask for the hearer agreement to follow the order.

3. The non importance of the command, so the speaker does not talk in a very demanding way and allow the hearer to refuse.

Some of the respondents' responses which the researchers considered as Appropriate are:

Table 3. Respondent's Responses

\begin{tabular}{|c|l|}
\hline $\begin{array}{c}\text { Respondent's } \\
\text { Number }\end{array}$ & \multicolumn{1}{c|}{ Responses } \\
\hline 4 & Hey X, make me a cup of tea \\
\hline 12 & A, can you make me a cup of tea now? I am so thirsty. \\
\hline 14 & $\begin{array}{l}\text { Hey (his/her name), would you like to make me a cup of tea? If no, it's } \\
\text { okay. }\end{array}$ \\
\hline 15 & $\begin{array}{l}\text { Hey (his/her name), would you like to make me a cup of tea? If no, it's } \\
\text { okay. }\end{array}$ \\
\hline 16 & Could you make me a cup of tea please \\
\hline 20 & Could you help me to make a cup of tea for me? Thank you \\
\hline 21 & (name), make me a cup of tea pls \\
\hline 22 & Could you please make a cup of a tea? And let's have a small chat. \\
\hline 23 & I'd like a cup of tea, please \\
\hline 28 & Can you make me a cup of tea, please? \\
\hline
\end{tabular}

The total responds from 29 respondents are as follow:

\section{- Appropriate Answers: 11}

*Author(s) Correspondence:

E-mail: rsilalahi@bundamulia.ac.id
- Inappropriate Answers: 14

- Unrelated Answers: 4 
Table 4. Total Respondent's Responses

\begin{tabular}{|c|c|c|c|c|}
\hline $\begin{array}{c}\text { Respondent } \\
\text { Number }\end{array}$ & Power & $\begin{array}{c}\text { Social } \\
\text { Distance }\end{array}$ & Imposition & Conclusion \\
\hline 1 & - & + & - & Inappropriate \\
\hline 2 & - & - & - & Inappropriate \\
\hline 3 & - & - & - & Inappropriate \\
\hline 4 & + & + & - & Appropriate \\
\hline 5 & - & + & - & Inappropriate \\
\hline 6 & - & - & - & Unrelated \\
\hline 7 & - & - & + & Inappropriate \\
\hline 8 & + & - & + & Inappropriate \\
\hline 9 & - & + & - & Inappropriate \\
\hline 10 & - & - & - & Unrelated \\
\hline 11 & - & + & - & Inappropriate \\
\hline 12 & + & + & - & Appropriate \\
\hline 13 & + & + & - & Unrelated \\
\hline 14 & + & + & - & Appropriate \\
\hline 15 & + & + & - & Appropriate \\
\hline 16 & + & + & - & Appropriate \\
\hline 17 & - & + & - & Unrelated \\
\hline 18 & - & - & - & Inappropriate \\
\hline 19 & - & + & - & Inappropriate \\
\hline 20 & + & + & - & Appropriate \\
\hline 21 & + & + & - & Appropriate \\
\hline 22 & + & + & - & Appropriate \\
\hline 23 & + & + & - & Appropriate \\
\hline 24 & - & + & - & Inappropriate \\
\hline 25 & - & - & - & Inappropriate \\
\hline 26 & - & + & - & Inappropriate \\
\hline 27 & + & - & - & Inappropriate \\
\hline 28 & + & + & - & Appropriate \\
\hline 29 & + & + & - & Appropriate \\
\hline
\end{tabular}

In this situation, most of the respondents are unable to give appropriate answers because even though they are in a higher position, they give order in a very polite manner without using their authority. Some of the respondents manage to give appropriate answers and the others give unrelated answers because it's incomplete.

* One of the respondents failed to complete all of the questions, however, the respondent's answer is still accepted. Thus, further questions are going to have 28 respondents.

\section{Item 3}

Your boss, a company manager, asked you, their secretary, to arrange a lunch with their friends as soon as possible. However, you currently were not able to do it since your phone was broken.

*Author(s) Correspondence:

E-mail: rsilalahi@bundamulia.ac.id 
Power $=(+)$; Social distance $=(-) ;$ Imposition $=(+)$

What would you say?

$\rightarrow$ My apology sir/madam, I'm afraid that I won't be able to arrange the lunch meeting because my phone is currently broken. But I'll finish it as soon as possible with another way.

The above answer provided by the researchers is considered as Appropriate because:

1. The existence of the power, thus as the hearer, we respond with additional title to the speaker which is 'Sir/Madam'. The formal way of speaking also included here.

2. The distant relation between the speaker and hearer, thus the hearer has to refuse in a very polite manner and give a reason why.

3. The importance of the command which the hearer understands, so the hearer will offer another way or do the request afterwards.

Some of the respondents' responses which the researchers considered as Appropriate are:

Table 5. Respondent's Responses

\begin{tabular}{|c|l|}
\hline $\begin{array}{c}\text { Respondent's } \\
\text { Number }\end{array}$ & \multicolumn{1}{c|}{ Responses } \\
\hline 6 & $\begin{array}{l}\text { I m gonna say "sorry, sir/maam. My phone was broken, maybe you want } \\
\text { to buy the new one for me? Hahahahahahhaa just kidding. Of course I } \\
\text { would say with my honesty that my phone was broken and i can't asks } \\
\text { her. }\end{array}$ \\
\hline 9 & $\begin{array}{l}\text { I'm afraid I could not do it now, since my phone is broken. But, I will ask } \\
\text { the personal assist staff to arrange it real soon. }\end{array}$ \\
\hline 10 & $\begin{array}{l}\text { I apologize, sir. my phone is broken, i am going to find a way, but it will } \\
\text { take a little time, is that alright }\end{array}$ \\
\hline 11 & $\begin{array}{l}\text { I am sorry, Miss/Mr. My phone was broken, and I cannot arrange your } \\
\text { lunch. But, I will make sure to do it soon woth other choices. }\end{array}$ \\
\hline 18 & $\begin{array}{l}\text { "Sorry sir/mam, my phone is broken so i can't do it now. Would you wait } \\
\text { for me to get another source to make the appointment?" }\end{array}$ \\
\hline 23 & $\begin{array}{l}\text { I'm sorry Mr.../ Mrs... (surname), I think I would not able to do that since } \\
\text { my phone was broken. }\end{array}$ \\
\hline 24 & $\begin{array}{l}\text { I'm sorry but my phone is broken, can I do it using another method? } \\
\text { way } \text { ? }\end{array}$ \\
\hline 25 & $\begin{array}{l}\text { I would but do you mind if it takes longer than usual? My phone is not } \\
\text { operable right now? }\end{array}$ \\
\hline 28 & $\begin{array}{l}\text { I apologize first, but my phone is currently not functioning. But I'll be } \\
\text { sure to find alternatives to do so. }\end{array}$ \\
\hline
\end{tabular}

*Author(s) Correspondence:

E-mail: rsilalahi@bundamulia.ac.id 
The total responses from 28 respondents are as follow:

- Unrelated Answers: 3

- Appropriate Answers: 17

- Inappropriate Answers: 8

Table 6. Total Respondent's Responses

\begin{tabular}{|c|c|c|c|c|}
\hline $\begin{array}{c}\text { Respondent } \\
\text { Number }\end{array}$ & Power & $\begin{array}{c}\text { Social } \\
\text { Distance }\end{array}$ & Imposition & Conclusion \\
\hline 1 & + & - & + & Unrelated \\
\hline 2 & - & + & + & Inappropriate \\
\hline 3 & - & - & - & Unrelated \\
\hline 4 & + & + & - & Inappropriate \\
\hline 5 & + & - & + & Appropriate \\
\hline 6 & + & - & + & Appropriate \\
\hline 7 & + & + & - & Inappropriate \\
\hline 8 & + & - & + & Appropriate \\
\hline 9 & + & - & + & Appropriate \\
\hline 10 & + & - & + & Appropriate \\
\hline 11 & + & - & + & Appropriate \\
\hline 12 & - & + & - & Inappropriate \\
\hline 13 & - & + & + & Inappropriate \\
\hline 14 & - & + & + & Inappropriate \\
\hline 15 & + & - & + & Appropriate \\
\hline 16 & - & + & - & Unrelated \\
\hline 17 & + & - & + & Appropriate \\
\hline 18 & + & - & + & Appropriate \\
\hline 19 & + & - & + & Appropriate \\
\hline 20 & - & + & + & Inappropriate \\
\hline 21 & - & + & + & Inappropriate \\
\hline 22 & + & - & + & Appropriate \\
\hline 23 & + & - & + & Appropriate \\
\hline 24 & + & - & + & Appropriate \\
\hline 25 & + & + & + & Appropriate \\
\hline 26 & + & - & + & Appropriate \\
\hline 27 & + & - & + & Appropriate \\
\hline 28 & + & - & + & Appropriate \\
\hline
\end{tabular}

In this situation, most respondents are able to answer appropriately and politely according to their position and understand the urgency of the situation. Some other respondents give inappropriate answer because they could not show their acknowledgement of the urgency of the matter.

*Author(s) Correspondence:

E-mail: rsilalahi@bundamulia.ac.id 
4. Item 4

You, a student from class A, wanted to ask someone from class B to help you promote an event that you were going to hold to their class. However, you were only acquainted with that person and have not had a proper conversation with them.

$$
\text { Power }=(-) ; \text { Social distance }=(-) ; \text { Imposition }=(-)
$$

What would you say?

$\rightarrow \mathrm{Hi}$, may I ask you to do a favor? So, I want to ask you to help me in promoting an event that is going to be held in your class. I would really appreciate your help, thank you.

The above answer provided by the researchers is considered as Appropriate because:

1. The non existence of the power, thus as the speaker, we may ask for a request in a impolite manner. The informal way of speaking also included here, although for a distant relation, the speaker may also speak in a formal way.

2. The distant relation between the speaker and hearer as acquaintances, thus the speaker talks in a polite manner. And by saying 'please' or the need to ask for the hearer agreement to do the request.

3. The non importance of the command, so the speaker doesn't talk in a very demanding way and allow the hearer to refuse.

Some of the respondents' responses which the researchers considered as Appropriate are:

Table 7. Respondent's Responses

\begin{tabular}{|c|c|}
\hline $\begin{array}{l}\text { Respondent's } \\
\text { Number }\end{array}$ & Responses \\
\hline 2 & $\begin{array}{l}\text { Eventhough we've never had a conversation before, we know that person } \\
\text { right? And they probably know us since maybe we are in the same batch } \\
\text { Maybe I would say greetings first, explain them about the event and ask } \\
\text { them if they could please help and would they mind }\end{array}$ \\
\hline 3 & $\begin{array}{l}\text { Hello. Are you from class B, right? I am from class A. We will hold an } \\
\text { event in your class, but I am not sure that all of you know much the } \\
\text { information. Could you please help me to publish this event to your } \\
\text { friends, please? Thank You. }\end{array}$ \\
\hline 4 & $\begin{array}{l}\text { Hey, I'm from class A, I want to ask for your help to promote my event in } \\
\text { your class if you are willing to do so }\end{array}$ \\
\hline 7 & $\begin{array}{l}\text { Sorry, may I ask for your help to promote an event in your class? I'm } \\
\text { asking you because I just know you from your class. Thank you. }\end{array}$ \\
\hline 10 & $\begin{array}{l}\mathrm{Hi} \text {, are you (their name) from class b? Well i am from class a, anyways, } \\
\text { have you heard about the event? Could you promote this to your } \\
\text { classmate? Thank you and i owe you, (their name) }\end{array}$ \\
\hline 18 & $\begin{array}{l}\text { "hey, sorry to bother you but would you mind helping me to promote an } \\
\text { event in your class? Your help would means a lot! Thank you" }\end{array}$ \\
\hline 20 & $\begin{array}{l}\text { (name), can you help me with something? Its something only you can } \\
\text { help me. I want you to help me promote an event to your friends. You are }\end{array}$ \\
\hline
\end{tabular}

*Author(s) Correspondence:

E-mail: rsilalahi@bundamulia.ac.id 


\begin{tabular}{|l|l|}
\hline & the only person I know in class b, can you help me ? \\
\hline 24 & $\begin{array}{l}\text { Hi! Would you mind helping me? I'm going to do an event, maybe you } \\
\text { can help me by promoting my event? }\end{array}$ \\
\hline 26 & Would you mind helping me in promoting the X event to your class? \\
\hline 28 & $\begin{array}{l}\text { 'Hello there, I am maria from Class A. I was wondering if you can } \\
\text { promote the event that I will do later on? It will be appreciated. Thank } \\
\text { you. }\end{array}$ \\
\hline
\end{tabular}

The total responses from 28 respondents are as - Unrelated Answers: 2 follow:

- Appropriate Answers: 18

- Inappropriate Answers: 8

Table 8. Respondent's Responses

\begin{tabular}{|c|c|c|c|c|}
\hline $\begin{array}{c}\text { Respondent } \\
\text { Number }\end{array}$ & Power & $\begin{array}{c}\text { Social } \\
\text { Distance }\end{array}$ & Imposition & Conclusion \\
\hline 1 & - & + & - & Inappropriate \\
\hline 2 & - & - & - & Appropriate \\
\hline 3 & - & - & - & Appropriate \\
\hline 4 & - & - & - & Appropriate \\
\hline 5 & - & + & - & Inappropriate \\
\hline 6 & - & + & - & Unrelated \\
\hline 7 & - & - & - & Appropriate \\
\hline 8 & - & - & - & Appropriate \\
\hline 9 & - & - & - & Appropriate \\
\hline 10 & - & - & - & Appropriate \\
\hline 11 & - & - & - & Appropriate \\
\hline 12 & - & + & - & Inappropriate \\
\hline 13 & - & - & - & Appropriate \\
\hline 14 & - & - & - & Appropriate \\
\hline 15 & - & - & - & Appropriate \\
\hline 16 & - & + & - & Unrelated \\
\hline 17 & - & + & - & Inappropriate \\
\hline 18 & - & - & - & Appropriate \\
\hline 19 & - & - & - & Appropriate \\
\hline 20 & - & - & + & Inappropriate \\
\hline 21 & - & + & - & Inappropriate \\
\hline 22 & - & - & - & Appropriate \\
\hline 23 & - & - & - & Appropriate \\
\hline 24 & - & - & - & Appropriate \\
\hline 25 & - & + & - & Inappropriate \\
\hline 26 & - & - & - & Appropriate \\
\hline 27 & - & + & - & Inappropriate \\
\hline 28 & - & - & - & Appropriate \\
\hline & - & & & \\
\hline & - & - & - & - \\
\hline
\end{tabular}

*Author(s) Correspondence:

E-mail: rsilalahi@bundamulia.ac.id 
In this situation, most respondents are able to answer appropriately and politely according to their position without acting too friendly with the acquaintance. The other respondents give inappropriate answers because of the over-friendliness of the utterances.

\section{Item 5}

You were paired to do a group assignment with a new student. The new student invited you to their house to finish the assignment; however, you were uncomfortable of the idea of coming to a house of someone who you did not know well.

$$
\text { Power }=(-) \text {; Social distance }=(-) ; \text { Imposition }=(+)
$$

What would you say?

I think it is better if we go to other place, what do you think? Let's go now.

The above answer provided by the researchers is considered as Appropriate because:

1. The non existence of the power, thus as the speaker, we may ask for a request in a impolite manner. The informal way of speaking also included here, although for a distant relation, the speaker may also speak in a formal way.

2. The distant relation between the speaker and hearer as acquaintances, thus the speaker talk in a polite manner without the need to offend the hearer. And by saying 'please' or the need to ask for the hearer agreement to do the request.

3. The importance of the situation, so the speaker only talk in a bit demanding way because of the influence of the distant relation. This can be seen from the respond of 'let's go' and 'now'.

Some of the respondents' respond which the researchers considered as Appropriate are:

Table 9. Respondent's Responses

\begin{tabular}{|c|l|}
\hline $\begin{array}{c}\text { Respondent's } \\
\text { Number }\end{array}$ & \multicolumn{1}{c|}{ Responses } \\
\hline 2 & $\begin{array}{l}\text { Maybe we should do it here ( in school or university ) since we have also } \\
\text { great facilities and don't you think it will take more our time to go to your } \\
\text { house }\end{array}$ \\
\hline 8 & $\begin{array}{l}\text { Ask that friend to do the assignment in another public place, for example } \\
\text { cafè, library, or any other place. Tell him/her that your house is quite far } \\
\text { from his/her house so you dont have to come to her/his house }\end{array}$ \\
\hline 9 & $\begin{array}{l}\text { How about meeting at the national library? My friends said that the } \\
\text { ambience is good, and we might have clues from the book. }\end{array}$ \\
\hline 11 & $\begin{array}{l}\text { I am sorry, but can we do the group assignment at other places such as } \\
\text { canteen, restaurant, or the others?? }\end{array}$ \\
\hline 18 & $\begin{array}{l}\text { "hey i really would like to go to your house, but wouldn't it be better if } \\
\text { we finish it off at the cafe so we can hang out at the same time?" }\end{array}$ \\
\hline 20 & Im afraid that would be a bit far from my place. What about we do it in \\
\hline
\end{tabular}

*Author(s) Correspondence:

E-mail: rsilalahi@bundamulia.ac.id 


\begin{tabular}{|l|l|}
\hline & another place? \\
\hline 23 & $\begin{array}{l}\text { I think it would be better for us to the the assignment in the school } \\
\text { library. }\end{array}$ \\
\hline 24 & Maybe we can do it somewhere else? Like coffee shop maybe? \\
\hline 27 & $\begin{array}{l}\text { Let's meet up outside, maybe at the mall. I don't wanna bother your } \\
\text { parents. }\end{array}$ \\
\hline 28 & uh.. I am very sorry, but can we do it in the library or cafetaria instead? \\
\hline
\end{tabular}

The total responses from 28 respondents are as

- Unrelated Answers: 1 follow:

- Appropriate Answers: 23

- Inappropriate Answers: 4

Table 10. Respondent's Responds

\begin{tabular}{|c|c|c|c|c|}
\hline $\begin{array}{c}\text { Respondent } \\
\text { Number }\end{array}$ & Power & $\begin{array}{c}\text { Social } \\
\text { Distance }\end{array}$ & Imposition & Conclusion \\
\hline 1 & - & + & + & Inappropriate \\
\hline 2 & - & - & + & Appropriate \\
\hline 3 & - & - & - & Inappropriate \\
\hline 4 & - & + & - & Inappropriate \\
\hline 5 & - & - & + & Appropriate \\
\hline 6 & - & - & + & Appropriate \\
\hline 7 & - & - & - & Unrelated \\
\hline 8 & - & - & + & Appropriate \\
\hline 9 & - & - & + & Appropriate \\
\hline 10 & - & - & + & Appropriate \\
\hline 11 & - & - & + & Appropriate \\
\hline 12 & - & + & + & Appropriate \\
\hline 13 & - & - & + & Appropriate \\
\hline 14 & - & - & + & Appropriate \\
\hline 15 & - & - & + & Appropriate \\
\hline 16 & - & - & + & Appropriate \\
\hline 17 & - & - & + & Appropriate \\
\hline 18 & - & - & + & Appropriate \\
\hline 19 & - & - & + & Appropriate \\
\hline 20 & - & - & + & Appropriate \\
\hline 21 & - & - & - & Inappropriate \\
\hline 22 & - & - & + & Appropriate \\
\hline 23 & - & - & + & Appropriate \\
\hline 24 & - & - & + & Appropriate \\
\hline 25 & - & - & + & Appropriate \\
\hline 26 & - & - & + & Appropriate \\
\hline 27 & - & - & + & Appropriate \\
\hline 28 & - & - & + & Appropriate \\
\hline & & & & \\
\hline & - & - & + & + \\
\hline
\end{tabular}

*Author(s) Correspondence:

E-mail: rsilalahi@bundamulia.ac.id 
In this situation, most respondents are able to answer appropriately and politely according to their position and without offending their friend. The other respondents give inappropriate answers because their answers are offended and, on the contrary, show a close relation with the friend.

\section{Item 6}

Your best friend had been talking about a game they really liked for days, but you were not that interested in games and you were starting to get bored in talking about games.

$$
\text { Power }=(-) ; \text { Social distance }=(+) ; \text { Imposition }=(-)
$$

What would you say?

$\rightarrow$ I don't like that game. Change the topic, I'm bored hearing about it.

The above answer provided by the researchers is considered as Appropriate because:

1. The non existence of the power, thus as the speaker, we may ask for a request in a impolite manner. The informal way of speaking also included here, although for a distant relation, the speaker may also speak in a formal way.

2. The close relation between the speaker and hearer as best friends, thus the speaker talks in a straightforward manner and give a reason why. And doesn't worry if the utterance may offend the hearer because they are close.

3. The non importance of the situation, so the speaker only talk in a bit demanding way because of the influence of the close relation, but other than that, the speaker also let the hearer to refuse their suggestion.

Some of the respondents' responses which the researchers considered as Appropriate are:

Table 11. Respondents' Responses

\begin{tabular}{|c|l|}
\hline $\begin{array}{c}\text { Respondent's } \\
\text { Number }\end{array}$ & \multicolumn{1}{c|}{ Responses } \\
\hline 1 & Can you stop talking about that games? I am getting bored, to be honest. \\
\hline 3 & $\begin{array}{l}\text { Please, can you changes the topic? I do not like a game so much. Maybe } \\
\text { you can change the topic that I am interested ? }\end{array}$ \\
\hline 4 & $\begin{array}{l}\text { can you stop talking about that I dont like it } \\
\text { "Could you're not talking about that?! Because it sounds boring, and I'm } \\
\text { not understand at all" }\end{array}$ \\
\hline 6 & $\begin{array}{l}\text { Guys, come on. Can you stop talking about game? Let me join your } \\
\text { conversation too. }\end{array}$ \\
\hline 7 & $\begin{array}{l}\text { Can we talk about another topic? I do understand you liked it. The thing } \\
\text { is, I don't. }\end{array}$ \\
\hline 12 & cant you stop talking about that? its boring \\
\hline 13 & Actually I didn't Interest to game that you talked. \\
\hline
\end{tabular}

*Author(s) Correspondence:

E-mail: rsilalahi@bundamulia.ac.id 


\begin{tabular}{|l|l|}
\hline 15 & $\begin{array}{l}\text { Heyy, can you change the topic because i get bored in talking about } \\
\text { games }\end{array}$ \\
\hline 26 & Would you please stop? I'm sick of it. \\
\hline
\end{tabular}

The total responses from 28 respondents are as - Unrelated Answers: 1 follow:

- Appropriate Answers: 22

- Inappropriate Answers: 5

Tabel 12. Respondents' Responds

\begin{tabular}{|c|c|c|c|c|}
\hline $\begin{array}{l}\text { Respondent } \\
\text { Number }\end{array}$ & Power & $\begin{array}{c}\text { Social } \\
\text { Distance }\end{array}$ & Imposition & Conclusion \\
\hline 1 & - & + & - & Appropriate \\
\hline 2 & - & - & - & Inappropriate \\
\hline 3 & - & + & - & Appropriate \\
\hline 4 & - & + & - & Appropriate \\
\hline 5 & - & + & - & Appropriate \\
\hline 6 & - & + & - & Appropriate \\
\hline 7 & - & + & - & Appropriate \\
\hline 8 & - & + & - & Appropriate \\
\hline 9 & - & + & - & Inappropriate \\
\hline 10 & - & + & - & Appropriate \\
\hline 11 & - & + & - & Inappropriate \\
\hline 12 & - & + & - & Appropriate \\
\hline 13 & - & + & - & Appropriate \\
\hline 14 & - & + & - & Appropriate \\
\hline 15 & - & + & - & Appropriate \\
\hline 16 & - & + & - & Unrelated \\
\hline 17 & - & + & - & Appropriate \\
\hline 18 & - & + & - & Appropriate \\
\hline 19 & - & + & - & Appropriate \\
\hline 20 & - & + & - & Appropriate \\
\hline 21 & - & - & - & Inappropriate \\
\hline 22 & - & + & - & Appropriate \\
\hline 23 & - & + & - & Appropriate \\
\hline 24 & - & + & - & Appropriate \\
\hline 25 & - & + & - & Appropriate \\
\hline 26 & - & + & - & Appropriate \\
\hline 27 & - & + & - & Appropriate \\
\hline 28 & - & - & - & Inappropriate \\
\hline
\end{tabular}

In this situation, most respondents are able to answer appropriately according to their position. As they have a close relation with their friend, the respondents respond honestly about their disinterest toward the game without feeling guilty or think the friend might get offended. While the inappropriate answers are because the respondents give polite answers

*Author(s) Correspondence:

E-mail: rsilalahi@bundamulia.ac.id 
even without being honest with their own opinion.

\section{Item 7}

You have a deadline for an assignment tomorrow, but you did not have time to finish it since you were busy with work. You wanted to try asking your close friend on whether they want to help you finish it or not.

$$
\text { Power }=(-) \text {; Social distance }=(+) ; \text { Imposition }=(+)
$$

What would you say?

$\rightarrow$ Hey, help me with my assignment. I don't have the time to do it since I've got so many works to do. I promise I'll treat you later!"

The above answer provided by the researchers is considered as Appropriate because:

1. The non existence of the power, thus as the speaker, we may ask for a request in a impolite manner. The informal way of speaking also included here, although for a distant relation, the speaker may also speak in a formal way.

2. The close relation between the speaker and hearer as close friends, thus the speaker talk in a straightforward manner and give a reason why. And doesn't worry if the utterance may offend the hearer because they are close. Although in this situation, the speaker may talk in a polite and kind manner to earn the hearer's sympathy so the hearer will help them.

3. The importance of the situation, so the speaker talks in very demanding way because of the influence of the close relation and the deadline of the task. This can be seen from how the speaker insist by using 'please', showing inability to do the task by themselves, and promising a treat as a token of thanks.

Some of the respondents' responses which the researchers considered as Appropriate are:

Table 13. Respondents' Responses

\begin{tabular}{|c|l|}
\hline $\begin{array}{c}\text { Respondent's } \\
\text { Number }\end{array}$ & \multicolumn{1}{c|}{ Responses } \\
\hline 2 & $\begin{array}{l}\text { Hey could you please help me. I can't finish it since I've been so busy } \\
\text { lately }\end{array}$ \\
\hline 4 & $\begin{array}{l}\text { bro, can you help me with my assignment? i'm busy with work and i dont } \\
\text { have time to do my assignment, if you can help me I'll do the same in } \\
\text { return one day }\end{array}$ \\
\hline 5 & $\begin{array}{l}\text { Hey, are you busy? I haven't touched my assignment but I think I have no } \\
\text { time to do it. I'm busy with my work. Can you help me please? I'll treat } \\
\text { you starbucks anyway }\end{array}$ \\
\hline 6 & $\begin{array}{l}\text { "Hey, would you mind to help me to finish my assignment? I dont know } \\
\text { how to do, because i got a lot of job. Please:(" }\end{array}$ \\
\hline 9 & please help me on this assignment, i need to finish it asap! \\
\hline 13 & Yo, can you help me to finish my assignment? We are friend, right? \\
\hline
\end{tabular}

*Author(s) Correspondence:

E-mail: rsilalahi@bundamulia.ac.id 


\begin{tabular}{|c|l|}
\hline 15 & $\begin{array}{l}\text { Hey, could you help me to finish my assignment because i were busy } \\
\text { with my work }\end{array}$ \\
\hline 19 & $\begin{array}{l}\text { Please help me finish my assignment, its due tomorrow, and i am in panic } \\
\text { now.. please help me? }\end{array}$ \\
\hline 20 & $\begin{array}{l}\text { (name), have you done your assignment yet? Can you help me to do it for } \\
\text { me? Im just yoo busy at work and dont have time to do it. If you can do it } \\
\text { for me i will repay you somehow }\end{array}$ \\
\hline 28 & $\begin{array}{l}\text { Hey Shelly, can you help me with my homework? I'll be sure to help you } \\
\text { back in the next assignment! Pretty please? }\end{array}$ \\
\hline
\end{tabular}

The total responses from 28 respondents are as follow:

- Unrelated Answers: 3

- Appropriate Answers: 18

- Inappropriate Answers: 7

Table 14. Respondents' Responses

\begin{tabular}{|c|c|c|c|c|}
\hline $\begin{array}{c}\text { Respondent } \\
\text { Number }\end{array}$ & Power & $\begin{array}{c}\text { Social } \\
\text { Distance }\end{array}$ & Imposition & Conclusion \\
\hline 1 & - & - & - & Inappropriate \\
\hline 2 & - & + & + & Appropriate \\
\hline 3 & - & - & + & Inappropriate \\
\hline 4 & - & + & + & Appropriate \\
\hline 5 & - & + & + & Appropriate \\
\hline 6 & - & + & + & Appropriate \\
\hline 7 & - & - & + & Inappropriate \\
\hline 8 & - & + & - & Unrelated \\
\hline 9 & - & + & + & Appropriate \\
\hline 10 & - & - & + & Inappropriate \\
\hline 11 & - & + & + & Appropriate \\
\hline 12 & - & - & + & Inappropriate \\
\hline 13 & - & + & + & Appropriate \\
\hline 14 & - & + & + & Appropriate \\
\hline 15 & - & + & + & Appropriate \\
\hline 16 & - & - & + & Unrelated \\
\hline 17 & - & - & + & Inappropriate \\
\hline 18 & - & - & + & Inappropriate \\
\hline 19 & - & + & + & Appropriate \\
\hline 20 & - & + & + & Appropriate \\
\hline 21 & - & + & + & Appropriate \\
\hline 22 & - & + & + & Appropriate \\
\hline 23 & - & + & + & Appropriate \\
\hline 24 & - & + & + & Appropriate \\
\hline 25 & - & + & + & Appropriate \\
\hline 26 & - & + & - & Unrelated \\
\hline 27 & - & + & + & Appropriate \\
\hline 28 & - & + & + & Appropriate \\
\hline & - & & & \\
\hline
\end{tabular}

*Author(s) Correspondence:

E-mail: rsilalahi@bundamulia.ac.id 
In this situation, most respondents are able to answer appropriately according to their position. They manage to express the urgency of the situation and request help from their close friend in informal manner. The other respondents give inappropriate answers because they couldn't express the urgency of the situation and request help in a polite manner.

\section{Item 8}

A lecturer chose you as the university's representative to join a debate competition in Singapore, but you were not confident in your ability and you wanted to refuse it.

$$
\text { Power }=(+) \text {; Social distance }=(-) ; \text { Imposition }=(-)
$$

What would you say?

$\rightarrow$ I'm sorry, Sir, I cannot join the debate for I'm not good enough about my skills, I have to learn more and have some courage, so that next time I'll be able to join the competition.

The above answer provided by the researchers is considered as Appropriate because:

1. The existence of the power, thus as the hearer, we respond with additional title to the speaker which is 'Sir/Madam'. The formal way of speaking also included here.

2. The distant relation between the speaker and hearer, thus the hearer have to refuse in a very polite manner and give a reason. It is possible to explain the reason in a longer utterance because of the formality.

3. The non importance of the situation because of the time duration before the competition, so the hearer responds in a calm manner.

Some of the respondents' responses which the researchers considered as Appropriate are:

Table 15. Respondents' Responses

\begin{tabular}{|c|l|}
\hline $\begin{array}{c}\text { Respondent's } \\
\text { Number }\end{array}$ & \multicolumn{1}{c|}{ Responses } \\
\hline 2 & $\begin{array}{l}\text { I would ask the reason why they choose me first politely and answer it } \\
\text { honestly And maybe I would say, I'm sorry I'm not good at handle my } \\
\text { nervous and I'm not that confident compare to others }\end{array}$ \\
\hline 4 & $\begin{array}{l}\text { Im sorry sir/madam, i want to join but i doubt my ability, you better } \\
\text { choose another person }\end{array}$ \\
\hline 5 & $\begin{array}{l}\text { I'm really thankful for the opportunity, Mam, but I think it's not my time } \\
\text { yet. }\end{array}$ \\
\hline 6 & $\begin{array}{l}\text { "Sorry, sir/maam. Actually, i'm not confident at all because im just lil bit } \\
\text { nervous to talking in public and im not capable to debate about } \\
\text { everything. Maybe, you could choose the right one but not me" }\end{array}$ \\
\hline 7 & $\begin{array}{l}\text { Sorry Mr/Mrs., but I'm not confident with my ability, maybe you can } \\
\text { choose other student which is better than me. }\end{array}$ \\
\hline
\end{tabular}

*Author(s) Correspondence:

E-mail: rsilalahi@bundamulia.ac.id 


\begin{tabular}{|c|l|}
\hline 10 & $\begin{array}{l}\text { I'm not sure about that, ma'am. It just... it's not my thing to speak in } \\
\text { front of lots of people.. is that okay if i refuse? I don't think i can win }\end{array}$ \\
\hline 11 & $\begin{array}{l}\text { I am sorry, Miss/Sir. I cannot be the university's representative for the } \\
\text { debate competition because I am not quite confident with my debate } \\
\text { ability. Please search for someone else to be the representative for the } \\
\text { debate competition. }\end{array}$ \\
\hline 15 & $\begin{array}{l}\text { I'm sorry sir/miss i can't because i'm not good enough and i were not } \\
\text { confident with my ability }\end{array}$ \\
\hline 18 & $\begin{array}{l}\text { "sir/mam it's an honour for me to be chosen as the representative, but i } \\
\text { don't feel like i am confident enough to be able to do it well" }\end{array}$ \\
\hline 21 & $\begin{array}{l}\text { Thanks for trust my ability, sir. I'd like to join the competition, but I } \\
\text { think I couldn't. I'm not confident to meet new people in public. }\end{array}$ \\
\hline
\end{tabular}

The total responses from 28 respondents are as - Unrelated Answers: 1 follow:

- Appropriate Answers: 15

- Inappropriate Answers: 12

Table 16. Respondents' Responses

\begin{tabular}{|c|c|c|c|c|}
\hline $\begin{array}{c}\text { Respondent } \\
\text { Number }\end{array}$ & Power & $\begin{array}{c}\text { Social } \\
\text { Distance }\end{array}$ & Imposition & Conclusion \\
\hline 1 & - & - & - & Inappropriate \\
\hline 2 & + & - & - & Appropriate \\
\hline 3 & - & + & - & Inappropriate \\
\hline 4 & + & - & - & Appropriate \\
\hline 5 & + & - & - & Appropriate \\
\hline 6 & + & - & - & Appropriate \\
\hline 7 & + & - & - & Appropriate \\
\hline 8 & + & - & - & Appropriate \\
\hline 9 & - & - & - & Inappropriate \\
\hline 10 & + & - & - & Appropriate \\
\hline 11 & + & - & - & Appropriate \\
\hline 12 & + & + & - & Inappropriate \\
\hline 13 & - & - & - & Inappropriate \\
\hline 14 & - & - & - & Inappropriate \\
\hline 15 & + & - & - & Appropriate \\
\hline 16 & - & - & - & Inappropriate \\
\hline 17 & - & - & - & Inappropriate \\
\hline 18 & + & - & - & Appropriate \\
\hline 19 & + & - & - & Appropriate \\
\hline 20 & - & - & - & Inappropriate \\
\hline 21 & + & - & - & Appropriate \\
\hline 22 & - & - & - & Inappropriate \\
\hline 23 & + & - & - & Appropriate \\
\hline 24 & - & - & - & Inappropriate \\
\hline & & & & \\
\hline
\end{tabular}

*Author(s) Correspondence:

E-mail: rsilalahi@bundamulia.ac.id 


\begin{tabular}{|c|c|c|c|c|}
\hline 25 & - & - & - & Unrelated \\
\hline 26 & - & + & - & Inappropriate \\
\hline 27 & + & - & - & Appropriate \\
\hline 28 & + & - & - & Appropriate \\
\hline
\end{tabular}

In this situation, most respondents are able to answer appropriately and politely according to their position which show their respect to the lecturer. However some other respondents answer inappropriately because of no titles are stated and some what impolite utterances toward the person with a higher position.

\section{CONCLUSION}

The aim of this research is to find out whether Non-Native English Speakers understand the method to perform Face Threatening Act, especially for the college students. It is important because people will definitely do FTA in daily life. However, the proper strategies have to be applied, based to the circumstances, in order to execute the FTA without creating minor issues in the relationship of each party.

For this reason, the researchers create a Discourse Completion Test to University students who are NNES to find out more about it. And as we can see in the DCT results, the result is that most of the respondents have appropriate answer, similar with the answer that the researchers had provided. The high and low level of FTA may vary depend on the context and the circumstances of the speaker and the hearer.

By giving this test to the University students, who are Indonesian Native Speaker, the researchers obtained the result that most of the respondents able to give appropriate answer with low level FTA in most of the situations which need politeness. This is natural for the culture of Indonesian people to always give a kind and polite respond to everyone. Nevertheless, all the results display the low level of FTA when the speaker is faced with the higher Power and positive Imposition and the high level of FTA when the speaker talks to the hearer with positive Social Distance and positive Imposition. So in conclusion, most of the respondents understand and are able to perform FTA appropriately.

\section{Acknowledgement}

This research is done as a part of class project of the $5^{\text {th }}$ semester students in English Language and Culture Department in Bunda Mulia University for BBI Journal in 2017. This work would not have been possible without the cooperation of all students. We all had done our best in order to bring this work to completion by investing our time and energy from DCT designation, sharing questionnaire link, to thorough analysis of the work.

We would like to thank Dr. Ronald Maraden Parlindungan Silalahi, SS, M. Hum as our supervisor, without your constant positive support and advices, this research won't finish well in the meantime. We also would like to thank English Language and Culture Department for the opportunity given to our class to prove our ability and knowledge by giving contribution to BBI Journal through this work.

Below are the names of people who deserve more credits for their hard work in their appointed task:

\footnotetext{
*Author(s) Correspondence:

E-mail: rsilalahi@bundamulia.ac.id
} 
1. Final author and editor

2. Head of each division

3. Grammar and content checker : Felyani (15150001)

4. All students in class of 2015 of English Language and Culture Department

\section{REFERENCES}

Austin, J. L. (1962). How to do things with words. Oxford: Clarendon Press. Retrieved from https://www.scribd.com/document/2064 31977/Austin-J-L-How-to-Do-Thingswith-Words-pdf.

Brown, P., \& Levinson, S. C. (1987). Politeness: Some universals in language usage. Cambridge: Cambridge University Press.

Brown, P., \& Levinson, S. C. (1999). Politeness: Some universals in language usage. In A. Jaworski, \& N. Coupland (Eds), The discourse reader $\left(2^{\text {nd }}\right.$ ed., $p p$. 311-323). Retrieved from http://pubman.mpdl.mpg.de/pubman/ite m/escidoc:64421/component/escidoc:22 25570/Brown\&SCL-

Politeness 1999.pdf.

Grice, H. P. (1975). Speech Acts. In Cole, P., and J.L. Morgan (Eds), Logic and conversation. New York: Academic Press (pp 41-58). Retrieved from http://www.cog.brown.edu/courses/cg45 $/$ lecture\%20slides/gricean\%20maxims.p df

Holmes, J. (2001). An introduction to sociolinguistics $\left(2^{\text {nd }}\right.$ Edition). London: Longman.

Lakoff, R. (1973). Politeness principle. In V. Margetan, G.K. Ratih, \& P.D. Ratri, Robin Lakoff's politeness principles.
Retrieved

from

https://www.academia.edu/9669467/RO BIN_LAKOFF_S_POLITENESS_PRI NCIPLES?auto $=$ download.

Moussu, L.M. (2006). Native and nonnative English speaking English as a second language teachers: Student attitudes, teacher self-perceptions, and intensive English administrator beliefs and practices (Doctoral Thesis). Retrieved from

https://files.eric.ed.gov/fulltext/ED4925 99.pdf.

Rose, K. R. (1994). On the validity of the discourse completion task in nonwestern contexts. Applied Linguistics, 15(1), 1-14. Retrieved from https://www.researchgate.net/publicatio n/30938123_On_the_Validity_of_Disco urse_Completion_Tests_in_NonWestern_Contexts 1 .

Searle, J. (1965). What is a Speech Act?. In M, Black (ed.), Philosophy in America, London: Allen and Unwin, (pp. 221239). Retrieved from http://jwood.faculty.unlv.edu//unlv/Artic les/SearleWhatIsASpeechAct.pdf.

Surveymonkey.com

*Author(s) Correspondence:

E-mail: rsilalahi@bundamulia.ac.id 